\title{
Values of Metabolizable Energy and Metabolization of Nutrients for Slow- and Fast-growing Birds at Different Ages
}

-Author(s)

\section{Santos FR' \\ Stringhini $J H^{\prime}$ \\ Oliveira PR' \\ Duarte $\mathrm{EF}^{\prime}$ \\ Minafra CS' \\ Café MB'}

Animal Science Department, Goiano Federal Institute, Rio Verde, Brazil

\section{ABSTRACT}

Two trials were performed to determine apparent metabolizable energy (AME) and AME corrected for zero nitrogen balance (AMEn) values and coefficients of apparent metabolizability of nitrogen (CAMN) and of ether extract (CAMEE) of slow- and fast-growing broilers (Isa label and Cobb, respectively) fed four different diets between 10 to 17 days or 28 to 35 days of age. The method of total excreta collection was applied. The tested feedstuffs were corn, whole corn germ (WCG), sorghum, and soybean meal (SBM). A randomized block experimental design was applied, with two treatments (breeds) and four replicates of ten animals each in the first trial, and four replicates of six animals each in the second trial. No differences in CAMN values were observed between the breeds; however, Isa Label birds presented higher CAMEE for all tested feedstuffs. The AME and AMEn values obtained in Isa Label chickens fed the corn diet were 5.75 and 3.44\% higher relative tothe Cobb birds, respectively. Breed did not influence AME and AMEn values of the other tested feedstuffs. Independently of breed, age influenced the AME and AMEn values of WCG, sorghum and SBM, suggesting that birds become utilize feed more efficiently as they age.

\section{INTRODUCTION}

In order to formulate economically viable feeds, it is important to know the nutritional value of feedstuffs, which requires determining their chemical composition, nutrient availability, and energy content and utilization by a given species (Generoso et al., 2008). Although feedstuffs are often evaluated for fast-growing chickens, few studies have been performed to determine feed nutrient utilization by slowgrowing chicken strains reared in alternative animal production systems.

Additional studies are required to elucidate nutrient utilization of protein- and energy-rich feeds used in slow-growing broilers, particularly because bird age, which is associated with the development of the gastrointestinal tract, may interfere with the nutritional evaluation of feeds, as mentioned by Calderano et al. (2012).

According to Mendonça et al. (2008), slow-growing broilers show increased energy metabolization capacity as they age. Therefore, the use of values of apparent metabolizable energy (AME) corrected for zero nitrogen balance (AMEn) derived from published tables to assess feeds may overestimate energy utilization by those birds during the early stages of life and underestimate it at older ages.

Considering that the growth rate of Isa Label chickens is slower than that of fast-growing broiler strains, their rates of digestive tract growth and enzyme production may be different from those of broilers selected to fast growth. This difference in gastrointestinal development may influence nutrient utilization, which has implications for the 
formulation of feeds for slow-growing chickens, which feeds are commonly formulated based on nutritional data derived from fast-growing breeds.

The current study was performed to determine the chemical composition, coefficients nutrient metabolization, and levels of apparent metabolizable energy and apparent metabolizable energy corrected for nitrogen of selected feedstuffs included in the diets of slow- and fast-growing broiler chickens at different ages.

\section{MATERIALS AND METHODS}

Two metabolism assays were performed in the poultry sector of the Federal Institute Goiano (Instituto Federal Goiano),Rio Verde campus, state of Goiás, Brazil. This project was approved by our institutional ethics committee for animal research under the protocol number 012/2012.

\section{Experimental Design, Animals, Housing and Diets}

The assays evaluated a broiler strain selected for slow growth rate (Isa Label) and one selected for high growth rate (Cobb) during the periods of 10 to 17 days and 28 to 35 days of age.

Energy values and coefficients of apparent metabolizability of nutrients were determined for each evaluated feedstuff. A randomized block design was applied, in which each cage represented one block with two treatments (breeds). During the first trial, there were four replicates of 10 birds each, and during the second trial, four replicates of six birds each. Data were submitted to joint analysis of variance to verify the effect of bird age on the evaluated variables.

In order to determine the coefficients digestibility and metabolizable energy levels, a reference diet was formulated, and the four test feeds were obtained by substituting $40 \%$ of the reference feed by the tested feedstuffs. Corn, sorghum, soybean meal (SBM) and whole corn germ (WCG) were evaluated. Nutrient utilization was determined in four groups of 10 birds of each breed that were fed the reference diet. The ingredient composition and calculated nutritional values of the reference diet are presented in Table 1.

Birds were housed in galvanized-wire cages measuring $0.90 \mathrm{~m} \times 0.60 \mathrm{~m} \times 0.45 \mathrm{~m}$. In the first experiment (10 to 17 days of age), 200 male broiler chickens from each breed, with initial average bodyweights of $130.33 \pm 6.51$ gand202.69 \pm 10.13 $\mathrm{g}$ for the Isa Label and Cobb breeds, respectively, were evaluated. In the second experiment (28 to 35 days of age), 120 chickens from each breed, with initial average body weights of $632.0 \pm 31.58 \mathrm{~g}$ and $1055.0 \pm 50.26 \mathrm{~g}$ for the Isa Label and Cobb breeds, respectively, were used.

Cages were equipped with trough feeders and nipple drinkers. Water and feed were provided ad libitum for the entire experimental period. The feeders were refilled twice a day to avoid waste.

Table 1 - Ingredient composition (\%) and calculated nutritional levels of the reference feed

\begin{tabular}{|c|c|c|c|}
\hline Ingredient & $\%$ of Natural Matter & Calculate & \\
\hline Corn grain & 57.57 & AME (kcal/kg) & 3.050 \\
\hline Soybean meal45\% & 34.66 & Crude Protein, \% & 21.14 \\
\hline Soybean oil & 3.03 & Digestible Lys, \% & 1.19 \\
\hline Dicalcium phosphate & 1.77 & Digestible Met+Cys, \% & 0.85 \\
\hline Limestone & 0.86 & Digestible Thr, \% & 0.72 \\
\hline Regular salt & 0.44 & Calcium, \% & 0.89 \\
\hline DL-Methionine & 0.28 & Available phosphorus, \% & 0.44 \\
\hline L-Lysine & 0.25 & Sodium, \% & 0.22 \\
\hline Avilamycin, 10\% & 0.01 & & \\
\hline Mineral Premix ${ }^{1}$ & 0.04 & & \\
\hline Vitamin Premix ${ }^{2}$ & 0.04 & & \\
\hline BHT Antioxidant & 0.01 & & \\
\hline Inert material ${ }^{3}$ & 1.00 & & \\
\hline Total & 100.00 & & \\
\hline
\end{tabular}

${ }^{1}$ Compostion per $\mathrm{kg}$ of the product: manganese - 75,000 mg; iron - 20,000 mg; zinc -50,000 mg; copper - 4,000 mg; cobalt - 200 mg; iodine - 1,500 mg and carrier q.s.p. -1,000 g. ${ }^{2}$ Composition per kg of the product: Folic acid - 1,600 mg/kg; Pantothenic acid - $29 \mathrm{~g} / \mathrm{kg} ;$ BHT - 5,000 mg/kg; Biotin - $60 \mathrm{mg} / \mathrm{kg} ; \mathrm{Niacin}-87 \mathrm{~g} / \mathrm{kg} ;$ Vitamin A - $20,000.000 \mathrm{lU} /$ kg; Vitamin B1 - 3,000 mg/kg; Vitamin B12 - 28,000 mcg/kg; Vitamin B2 - 12 g/kg; Vitamin B6 - 6,000 mg/kg; Vitamin D3 - 5,000,000 IU/kg; Vitamin E - 40,500 IU/kg; Vitamin $\mathrm{K} 3-4,800 \mathrm{IU} / \mathrm{kg}$ and carrier q.s.p. $-1,000 \mathrm{~g}$

${ }^{3}$ Washed sand 


\section{Experimental Procedure and Chemical Analysis}

Energy values and coefficients of apparent metabolizability of nitrogen (CAMN) and of ether extract (CAMEE) were determined using the method of total excreta collection (Sakomura \& Rostagno, 2007). Birds were submitted to four-day adaptation period of to the cages and to the experimental diets before the period of four days of excreta collection, performed daily at 8:00 am and 3:00 pm. An aluminum tray lined with a plastic sheet was placed under each cage for excreta collection.

Excreta samples, tested feedstuffs, and experimental feeds were analyzed in the laboratory of Animal Nutrition of the Federal Institute Goiano to determine dry matter (DM), nitrogen $(N)$, and gross energy (GE) contents. Tested feedstuffs were also analyzed for crude fiber (CF), ether extract (EE) crude protein $(\mathrm{CP})$, ash (A), and nitrogen-free extract (NFE) contents according to the protocol of Silva \& Queiroz (2002). Total amino acid levels of the feedstuffs were analyzed by high-performance liquid chromatography (HPLC) at ADISSEO, a company that provides technical animal nutrition support.

\section{Calculation of Variables}

The variables AME and AMEn were calculated using the equations described by Matterson et al. (1965). The following equations were applied to calculate CAMN and CAMEE:

CAM of a nutrient $(\%)=$ Nutrient intake - Nutrient excretion $\times 100$ Nutrient intake

The AME, AMEn, CAMN, and CAMEE values of the experimental diets were evaluated for each rearing period.

\section{Statistical analyses}

To verify the effect of bird age on the coefficients of nutrient metabolizability, and AME and AMEn values were assessed by conjunct analysis of variance using the Sisvar software (System for Analysis of Variance, version 5.3, Ferreira et al., 2011). The differences between breeds and age means were determined by the Tukey's test at 5\% probability level.

\section{RESULTS AND DISCUSSION}

Small variations were observed in the energy content of the tested feedstuffs (Table 2 ) relative to literature reports (Brito et al., 2005; Generoso et al., 2008; Mello et al., 2009). Total amino acids content of the tested feedstuffs (Table 3) were consistent with those observed by Freitas et al. (2005) and Rostagno et al. (2011).

Table 2 - Chemical composition and gross energy values of the tested feedstuffs.

\begin{tabular}{lcccc}
\hline & Corn & Whole corn germ & Sorghum & Soybean meal \\
\hline DM (\%) & 89.62 & 88.98 & 90.22 & 88.50 \\
EE (\%) & 4.64 & 10.03 & 3.15 & 3.24 \\
CP (\%) & 8.41 & 10.96 & 9.32 & 47.70 \\
CF (\%) & 1.93 & 2.61 & 2.72 & 3.71 \\
A (\%) & 1.20 & 2.74 & 1.53 & 6.51 \\
NFE (\%) & 73.44 & 58.88 & 72.53 & 31.15 \\
GE (kcal/kg) & 3.947 & 4.234 & 3.899 & 4.267 \\
\hline
\end{tabular}

DM: dry matter, EE: ether extract, CP: crude protein, CF: crude fiber, A: ash, NFE: nitrogen-free extract, GE: gross energy

Table 3 - Total amino acid content of the tested feedstuffs.

\begin{tabular}{lcccc}
\hline Amino acid & Corn & Whole corn germ & Sorghum & Soybean meal \\
\hline Lysine & 0.22 & 0.40 & 0.17 & 2.90 \\
Methionine & 0.15 & 0.17 & 0.14 & 0.63 \\
Cysteine & 0.14 & 0.16 & 0.13 & 0.64 \\
\hline Arginine & 0.42 & 0.76 & 0.44 & 3.39 \\
\hline Threonine & 0.27 & 0.50 & 0.31 & 1.80 \\
Glycine & 0.28 & 0.50 & 0.31 & 2.04 \\
Serine & 0.40 & 0.53 & 0.48 & 2.48 \\
Valine & 0.26 & 0.38 & 0.34 & 2.04 \\
Isoleucine & 0.17 & 0.32 & 0.26 & 1.87 \\
Histidine & 0.22 & 0.30 & 0.21 & 1.52 \\
Phenylalanine & 0.32 & 0.43 & 0.44 & 2.13 \\
Tyrosine & 0.24 & 0.40 & 0.29 & 1.80 \\
Aspartic Acid & 0.48 & 0.78 & 0.69 & 4.30 \\
Glutamine & 1.50 & 1.35 & 2.15 & 7.70 \\
Alanine & 0.47 & 0.58 & 0.72 & 1.86 \\
\hline Proline & 0.81 & 0.80 & 0.89 & 2.14 \\
\hline
\end{tabular}

According to Calderano et al., (2010), variations in the chemical and energy composition of feedstuffs may occur for several reasons, such as differences in cultivar, as well as growth, soil, and weather conditions and processing to which the source material is exposed.

The CAMN of the feedstuffs was not influenced by broiler breed or age, except for WCG. Isa Label birds presented CAMEE values $11.74 \%, 18.76 \%$ and $46.54 \%$ greater than those obtained Cobb broilers for corn, WCG, and SBM, respectively (Table 4). 
Table 4 - Coefficient of apparent metabolizability of nitrogen (CAMN, \%) and ether extract (CAMEE, \%) of the tested feedstuffs fed to slow-growing (Isa Label) and fast-growing (Cobb) broilers.

\begin{tabular}{|c|c|c|c|c|c|c|c|}
\hline \multirow[t]{3}{*}{ Feed } & \multirow{3}{*}{$\begin{array}{l}\text { Age } \\
\text { (days) }\end{array}$} & \multirow{2}{*}{\multicolumn{2}{|c|}{$\begin{array}{c}\text { CAMN, }(\%) \\
\text { Breed }\end{array}$}} & \multirow[t]{3}{*}{ Mean } & \multicolumn{2}{|c|}{ CAMEE, (\%) } & \multirow[t]{3}{*}{ Mean } \\
\hline & & & & & & & \\
\hline & & Isa Label & Cobb & & Isa Label & Cobb & \\
\hline \multirow{4}{*}{ Corn } & 10 to 17 & 88.19 & 90.08 & $89.13 a$ & 92.29 & 81.87 & $87.08 a$ \\
\hline & 28 to 35 & 92.69 & 85.48 & $89.09 a$ & 94.34 & 85.16 & $89.75 a$ \\
\hline & Mean & $90.44 \mathrm{~A}$ & $87.78 \mathrm{~A}$ & & $93.32 \mathrm{~A}$ & $83.51 \mathrm{~B}$ & \\
\hline & $C V_{,}(\%)^{1}$ & \multicolumn{2}{|c|}{6.62} & \multicolumn{4}{|c|}{9.65} \\
\hline \multirow{4}{*}{ Whole corn germ } & 10 to 17 & 76.35 & 76.02 & $76.18 b$ & 80.74 & 57.34 & $69.04 b$ \\
\hline & 28 to 35 & 85.99 & 87.13 & $86.56 a$ & 86.25 & 83.28 & $84.77 a$ \\
\hline & Mean & $81.17 \mathrm{~A}$ & $81.58 \mathrm{~A}$ & & $83.50 \mathrm{~A}$ & $70.31 \mathrm{~B}$ & \\
\hline & $C V_{1}(\%)^{1}$ & \multicolumn{2}{|c|}{6.48} & \multicolumn{4}{|c|}{12.73} \\
\hline \multirow{4}{*}{ Sorghum } & 10 to 17 & 92.53 & 90.39 & $91.46 a$ & 87.3 & 74.58 & $80.94 a$ \\
\hline & 28 to 35 & 90.29 & 84.24 & $87.27 a$ & 90.85 & 84.37 & $87.61 a$ \\
\hline & Mean & $91.41 \mathrm{~A}$ & $87.31 \mathrm{~A}$ & & 89.07A & $79.48 \mathrm{~A}$ & \\
\hline & $C V_{,}(\%)^{1}$ & \multicolumn{2}{|c|}{6.02} & \multicolumn{4}{|c|}{13.22} \\
\hline \multirow{4}{*}{ Soybean meal } & 10 to 17 & 46.74 & 46.11 & $46.43 a$ & 71.45 & 51.55 & $61.50 a$ \\
\hline & 28 to 35 & 50.41 & 46.64 & $48.53 a$ & 80.32 & 52.38 & $66.35 a$ \\
\hline & Mean & $48.58 \mathrm{~A}$ & $46.38 \mathrm{~A}$ & & $75.89 \mathrm{~A}$ & $51.96 \mathrm{~B}$ & \\
\hline & $C V_{1}(\%)^{1}$ & \multicolumn{2}{|c|}{13.19} & \multicolumn{3}{|c|}{14.77} & \\
\hline
\end{tabular}

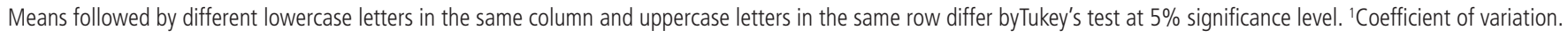

Chickens fed WCG between 28 and 35 days of age presented with $13.63 \%$ and $22.78 \%$ higher CAMN and CAMEE values, respectively, when compared with chickens fed with the same feedstuffs between 10 and 17 days of age (Table 4). According to Brumano et al., (2006), young broilers present lower nutrient digestion and absorption capacity compared with older broilers because their digestive system is still under development. On the other hand, older broilers have a fully developed digestive system, with a larger digestive tract and higher enzyme production and gastric secretions, resulting in better feed utilization.

The effect of age on nutrient utilization was most obvious in the birds fed WCG. As show in Table 2, WCG presented the highest ether extract content $(10.03 \%)$, and excessive availability of lipids can be a limiting factor for the digestion of WCG during the first days of the broiler's life (Maiorka et al., 2004).

Significant differences in ether extract metabolizability were observed between breeds, except for sorghum. According to Bertechini (2006), several factors related to the chemical composition of a given molecule and the digestive maturity of the bird can influence lipid absorption.

We did not observe any significant interactions between breed and age for any of the tested feedstuffs in relation to energy utilization (Table 5). As the birds aged, AME (kcal/ $/ \mathrm{kg})$ and AMEn $(\mathrm{kcal} / \mathrm{kg})$ of WCG, sorghum, and SBM values increased, except for corn, which values were not affected by age.
Based on studies on other feedstuffs, we expected an age-dependent increase in corn energy metabolization in the studied breeds. However, Mello et al. (2009) observed that age-dependent changes in AME content were not observed in corn, wheat bran, or poultry by product meal despite an age-dependent increase in AME and AMEn values detected in other feedstuffs (sorghum, soybean meal, and blood plasma). These results suggest that the energy use of birds of different ages changes according to how feedstuffs are processed by the digestive enzymes at the different stages of the bird's life.

When fed the corn diet, Isa Label chickens presented AME and AMEn values 5.75\% (177.98 $\mathrm{kcal} / \mathrm{kg})$ and $3.44 \%(105.94 \mathrm{kcal} / \mathrm{kg})$ higher than those determined in Cobb birds, respectively. The AME and AMEn values of the other tested feedstuffs were not influenced by breed (Table 5). Energy utilization of WCG, sorghum, and particularly SBM was not statistically different between breeds, however, slow-growing birds presented higher corn energy utilization. Isa Label birds tended to show higher AME values (71.6, 42.57, and $85.10 \mathrm{kcal} / \mathrm{kg}$ ) than Cobb birds, which accounted for increases of $2.56,1.39$, and $3.85 \%$ for WCG, sorghum and SBM, respectively.

Santos et al. (2005) reported that there is large difference in the maximum growth rate between Cobb and Isa Label breeds. The authors verified that the inflection point of the growth curve corresponding 
Table 5 - Apparent metabolizable energy (AME) and apparent metabolizable energy corrected for nitrogen balance (AMEn) values of the tested feedstuffs fed to slow-growing (Isa Label) and fast-growing (Cobb) broilers.

\begin{tabular}{|c|c|c|c|c|c|c|c|}
\hline \multirow[t]{3}{*}{ Feed } & \multirow{3}{*}{$\begin{array}{c}\text { Age } \\
\text { (days) }\end{array}$} & \multicolumn{2}{|c|}{ AME, (kcal/kg) } & Mean & \multicolumn{2}{|c|}{ AMEn, (kcal/kg) } & \multirow[t]{2}{*}{ Mean } \\
\hline & & \multicolumn{2}{|c|}{ Breed } & \multicolumn{3}{|c|}{ Breed } & \\
\hline & & Isa Label & Cobb & & Isa Label & Cobb & \\
\hline \multirow{4}{*}{ Corn } & 10 to 17 & 3240.7 & 3046.7 & $3158.7 a$ & 3156.9 & 3036.1 & $3096.5 a$ \\
\hline & 28 to 35 & 3305.5 & 3143.5 & $3200.3 a$ & 3221.3 & 3130.3 & $3175.8 \mathrm{a}$ \\
\hline & Mean & $3273.1 \mathrm{~A}$ & 3095.1B & & $3189.1 \mathrm{~A}$ & $3083.18 \mathrm{~B}$ & \\
\hline & $C V_{1}(\%)^{1}$ & \multicolumn{2}{|c|}{3.47} & \multicolumn{4}{|c|}{3.50} \\
\hline \multirow{4}{*}{$\begin{array}{l}\text { Whole corn } \\
\text { germ }\end{array}$} & 10 to 17 & 2762.6 & 2633.1 & $2697.8 b$ & 2686.5 & 2633.8 & $2661.7 \mathrm{~b}$ \\
\hline & 28 to 35 & 2978.2 & 2964.9 & $2971.3 a$ & 2896.8 & 2951.1 & $2923.9 a$ \\
\hline & Mean & $2870.4 \mathrm{~A}$ & $2798.8 \mathrm{~A}$ & & $2791.6 \mathrm{~A}$ & $2792.5 \mathrm{~A}$ & \\
\hline & $C V_{1}(\%)^{1}$ & \multicolumn{2}{|c|}{5.08} & \multicolumn{4}{|c|}{5.11} \\
\hline \multirow{4}{*}{ Sorghum } & 10 to 17 & 3276.2 & 3214.3 & $3245.1 b$ & 2984.5 & 2961.6 & $2973.1 \mathrm{~b}$ \\
\hline & 28 to 35 & 3473.9 & 3484.2 & $3479.1 \mathrm{a}$ & 3222.0 & 3159.8 & $3190.9 a$ \\
\hline & Mean & $3375.0 \mathrm{~A}$ & $3349.3 \mathrm{~A}$ & & $3103.3 \mathrm{~A}$ & $3060.7 \mathrm{~A}$ & \\
\hline & $C V_{,}(\%)^{1}$ & \multicolumn{2}{|c|}{5.95} & \multicolumn{4}{|c|}{5.86} \\
\hline \multirow{4}{*}{ Soybean meal } & 10 to 17 & 2363.4 & 2226.6 & $2295.0 b$ & 2261.9 & 2140.3 & $2201.1 \mathrm{a}$ \\
\hline & 28 to 35 & 2393.8 & 2346.4 & $2370.1 \mathrm{a}$ & 2325.1 & 2275.9 & $2300.5 b$ \\
\hline & $C V_{1}(\%)^{1}$ & \multicolumn{2}{|c|}{4.79} & \multicolumn{4}{|c|}{4.76} \\
\hline & Mean & $2378.6 \mathrm{~A}$ & $2286.5 \mathrm{~A}$ & & $2293.5 A$ & $2208.1 \mathrm{~A}$ & \\
\hline
\end{tabular}

Means followed by different lowercase letters in the same column and uppercase letters in the same row differ by Tukey's test at $5 \%$ significance level. ${ }^{1}$ Coefficient of variation.

to the moment at which growth decelerates and leads to a decrease in the metabolic rate of the bird occurs at 37 days of age in male Cobb birds and at 52 days of age in Isa Label. Considering the growth rate of Cobb chickens, we assumed that the higher positive nitrogen balance values obtained by Cobb breed broilers at 10 to 17 and 28 to 35 days of age resulted in a smaller AMEn difference between Cobb and Isa Label, which emphasizes the importance of considering growth rate when formulating feeds (Table 5).

The trend of the smaller difference in WCG and sorghum AMEn values between breeds observed in this study may be explained by the correction for nitrogen balance (body nitrogen gain or loss), which standardizes and reduces the variation in energy values of the feedstuffs measured under different conditions (Sakomura \& Rostagno, 2007). According to those authors, when organic molecules are oxidized, energy is utilized in the metabolic processes and produces heat increment. Therefore, energy availability represents the sum of the energy increments during the digestion of protein, starch, and lipids. In the present study, differences between breeds regarding nitrogen metabolization were not analyzed because carbohydrate utilization was not quantified. However, the greater lipid digestibility may have contributed for the greater energy availability (AME and AMEn) of the corn for the slow-growing birds.
According to Rougiere et al., (2009) and Verdal et al. (2010), birds with larger gastric compartments (proventriculus and gizzard) tend to present more effective nutrient utilization compared with birds that show greater development of the small intestine. Thus, the higher energy use of slow-growing birds can be attributed to the peculiarities of the digestive organs of Isa Label broilers because they present with higher proventriculus and gizzard relative weight compared with Cobb broilers, as observed by Santos et al. (2005). Similarly to our study, Rougiere et al. (2009) also analyzed broiler breeds with different digestion efficiencies at 21 days of age and determined AMEn values and nutrient digestibility of grain-based pelleted feeds. The authors verified that the birds with larger gastric compartments presented 3.5, 5.6, 5.8 and $0.5 \%$ higher AMEn and lipid, protein and starch digestion, respectively, compared with breeds with smaller proventriculus and gizzard and larger small intestine. These studies suggest that the high proventriculus and gizzard relative weights of Isa Label birds may contribute to better gastric processing of the feeds, optimizing intestinal function, and consequently, improving nutrient utilization.

There are few studies evaluating feed energy utilization by slow-growing broilers. However, the AMEn values determined for both breeds and ages in the present studies are consistent with literature findings (Generoso et al., 2008; Calderano et al., 2010; Rostagno et al., 2011). 
Energy utilization values determined in the present study were age-dependent, but no considerable differences were observed between slow- and fastgrowing broilers. Therefore, future studies analyzing metabolizable energy values of the feedstuffs used in the formulation of feeds for broilers with slow growth rates should be conducted to update the energy values in the published nutritional tables according to age. Such information is essential for the optimization of feed formulation for slow-growing birds. In particular, these birds are marketed relatively older than fastgrowing chickens, and therefore, may present different nutrient utilization.

\section{ACKNOWLEDGEMENTS}

The authors would like to thank CAPES (Coordination of Improvement of Higher Education Personnel) for funding this research study. We also thank ADISSEO for the analyses of total amino acids contents of the tested feedstuffs.

\section{REFERENCES}

Bertechini AG. Nutrição de monogástricos. Lavras: Editora UFLA; 2006.

Brito AB, Stringhini JH, Cruz CP, Xavier SAG, Silva LAF, Café MB, Leandro NSM. Avaliação nutricional do gérmen integral de milho para aves. Ciência Animal Brasileira 2005;6(1):19-26.

Brumano G, Gomes PC, Albino, LFT, Rostagno HS, Generoso R A R, Schmidt M.Composição química e valores de energia metabolizável de alimentos protéicos determinados com frangos de corte em diferentes idades. Revista Brasileira de Zootecnia 2006;35(6):2297-2302.

Calderano AA, Gomes PC, Albino LFT, Rostagno HS, Souza RM, Mello HHC. Composição química e energética de alimentos de origem vegetal determinada em aves de diferentes idades. Revista Brasileira de Zootecnia 2010;39(2):320-326.

Ferreira DF. Sisvar: a computer statistical analysis system. Ciência Agrotécnica 2011:35: 1039-1042
Freitas ER, Sakomura NK, Neme R, Santos, A.L, Fernandes JBK. Efeito do processamento da soja integral sobre a energia metabolizávele a digestibilidade dos aminoácidos para aves. Revista Brasileira de Zootecnia 2005;34(6):1938-1949.

Generoso RAR, Gomes PC, Rostagno HS, Albino FT, Barreto LT, Brumano G.Composição química e energética de alguns alimentos para frangos de corte em duas idades. Revista Brasileira de Zootecnia 2008;37(7):1251-1256.

Maiorka A, Santin E, Silva AVF, Routman K S, Pizauro Jr. JM, Macari M. Effect of Broiler Breeder Age on Pancreas Enzymes Activity and Digestive Tract Weight of Embryos and Chicks. Brazilian Journal of Poultry Science 2004;6(1):19-22.

Matterson LS, Potter LM, Stutz MW, Singsen EP. The metabolisable energy of feed ingredients for chickens [research report 7]. New Haven: Connecticut Agricultural Experiment Station; 1965.

Mello HHC, Gomes PC, Rostagno HS, Albino LFT, Souza RM, Calderano AA. Valores de energia metabolizável de alguns alimentos obtidos com aves de diferentes idades. Revista Brasileira de Zootecnia 2009;38(5): 863-868.

Mendonça MO, Sakomura NK, Santos FR, Freitas ER, Fernades JBK, Barbosa NAA. Níveis de energia metabolizável para machos de corte de crescimento lento criados em semiconfinamento. Revista Brasileira de Zootecnia 2008;37(8):1433-1440.

Rostagno HS, Albino LFT, Donzele JL, Gomes PC, Oliveira RFM, Lopes DC, Ferreira AS, Barreto SLT, Euclides RF. Brazilian tables for poultry and swine: composition of feedstuffs and nutritional requirements. $3 \mathrm{rd}$ ed. Viçosa: UFV; 2011.

Rougiére N, Gomes J, Mignon-Grasteau S, Carré B. Effects of diet particle size on digestive parameters in D+ and D- genetic chicken lines selected for divergent digestion efficiency. Poultry Science 2009;88(1)1206-1215.

Sakomura NK, Rostagno HS. Métodos de pesquisa em nutrição de monogástricos. Jaboticabal: Funep; 2007

Santos AL, Sakomura NK, Freitas ER, Sá Fortes CML, Carrilho ENVM, Fernandes JBK. Estudo do crescimento, desempenho, rendimento de carcaça e qualidade de carne de três linhagens de frango de corte. Revista Brasileira de Zootecnia 2005;34(5):1589-1598.

Silva DJ, Queiroz AC. Análise de alimentos (métodos químicos e biológicos). $3^{\mathrm{a} e d .}$ Viçosa: Editora UFV; 2002. 235p

Verdal H, Mignon-Grasteau S, Jeulin C, Le Bihan-Duval E, Leconte M, Mallet S, Martin C, Narcy A. Digestive tract measurements and histological adaptation in broiler lines divergently selected for digestive efficiency. Poultry Science 2010;89(1):1955-1961. 